\section{WATER RESOURCES IN NEPAL: INSTITUTIONAL ANALYSIS BASED ON LEGAL PROVISIONS}

Shyamu Thapa Magar

\section{Introduction}

Natural resources are fundamental to life and are the basis of livelihood for human beings as well as animals. Water resources also play important role for survival and prospects for biotic environment. For the livelihood activities, all kinds of sources of water are important to the viability of ecosystem. Water resources come in different forms and have multiple uses. Water is present in surface stocks (lakes, ponds) and flows (rivers), as groundwater in aquifers or as soil moisture. The multiple sources and multiple uses of water resources means the competition between various stakeholders with various interests, especially since water users often involves externalities whereby secondary costs or benefits do not accrue to the water users themselves (Soussan, 1998:181).

The vitality of water for all living creature is explained by showing its scarcity in preset situation that water is in short supply in many parts of the region of Nepal. Water quantity as well as water quality issues are becoming matters of increasing concern. With growing population and intensification of the present agricultural practices, the pressure on water and the need for sustainable water management is increasing due to the growing demand for domestic consumption and agricultural use, which is shown as the importance of water in the life of Yarsha Khola people "without water no life" quotation (Merz, Shrestha and Dhakal et.al.2003:34).

Bandaragoda (2000,1-3) writes in the preface of her "Five Regional Study on Development of Effective Water Management Institutions" the definition of the term "Institution" suggested the framework for Institutional analysis focusing on three pillars such as Laws, policies and administration. The Institutional environment of human actions is seen as a necessary condition for management performance. Effectiveness of water management institutions, therefore, is seen in their ability to provide an appropriate, adequate structure to human actions involved in water management, a structure which can bee used with least transaction costs.

According to Bandaragoda, the term institution is used commonly in our daily life as taken for granted without knowing its real meanings that might have different meanings depending upon the situation and the context. In sociology, an institution is "an organized, established, procedure" (Jepperson, 1991). These procedures are represented as constituent rules of society, or "rules of the game". The Institution defined by Durkheim coated by Bandaragoda (2000:3) is seen as the functions of society by comparing the biological organism as their cause and effect relationship among organs claims that an institution, norms, tradition, or whatever, will be maintained as a result of positive social effects. Institutions set the ground rules (Taylor, 1991:283) for resource use and established the incentives, informations, and compulsions that guide economic outcomes.

Bandaragoda coats Merrey (1993) explaining that institution can be both formal and informal. Informal practices become rules in their own customs after many years of practice accepted by the society. Behavioral roles of individuals and groups in a given context of 
human interaction, aimed to a specified set of objectives are defined as informal institutions which persist as a valuable and useful for the society. Informal institutions have its own local rules and regulations based on customary systems which are very practical and regulate its members in every social, economic and political affair among various indigenous and ethnic organizations (Bhattachan, 1997:23, Dhakal, 1996:39-49). For the enforcement of laws, rules and regulations, institutions helped to provide the basic structure to the process as the procedures including the penalties or sanctions for violations, and sometimes rewards for compliance. In general, the definition given above as well as the terminology used in practice tried to defined the policies and objectives of the institutions its rules, and regulations, and core values of the organization such as operational plans and procedures, accountability, incentive mechanisms, norms, traditional practices and customs (Bandaradoga, 2000:5).

To use water resources in equitable basis and to achieve a sustainable development and management of water resources, it has become necessary to built country's capacity to plan and manage its resources and to implement water resources policies that incorporate principles such as water conservation, cost recovery, stakeholder participation, environmental protection etc. Focusing on these issues, national policies, rules and regulations based on water resources has been studied and tried to find out the gaps in coordination and linkages between upper level and lower level institutions in national and local level. This study will also try to find out the existing institutional practices in local and national level based on the legal provisions. This study will be also helpful for those who are interested on the legal provisions of water resources management in legal anthropological aspects.

\section{Key points: Water, policy, Institutions, and Management}

The main objective of this paper is to carry out analysis on water management and arrangements in existing water sectoral institutions in Nepal in terms of their appropriateness and adequacy for the management of water resources, which will focus on broad areas of inquiry of water policy, water laws and water administration in Nepal.

\section{Material and Methods}

Primary and mostly secondary informations were collected for the fulfillment of writing this paper. Various relevant water related policies, government's circulars and related official publications were reviewed to analyze the existing rules and regulations to find out the gaps during its implications. Fieldwork was done in the Indrawati river basin area in 2001 to find out the local processes on using the water resources in their daily life, local water resource management procedure and distribution among villagers in irrigation system. Key informant interviews were conducted with (District Local Development Office, Chief Officer of District Drinking Water Corporation Office and from District Irrigation Office) as well as focused group discussions were held among Water User Groups to find out the local distribution process and its existing practices in irrigation sector as well as linkages between government and local institutions.

\section{Water Related Legal provisions in National level: Water policy and its development}

The goal of water resource development in the country is to tap and utilize water resources for gaining social benefits by ensuring the participation of the private sector. It is believed that developing potential huge water resources of the country will not only meet the country's energy demand but also help to develop agriculture and 
industrial sectors, facilitate socio-economic development, and contribute to poverty alleviation by covering the objectives of the Constitution of the Kingdom of Nepal 2047 focusing on the utilization of the natural resource of the country in sustainable manner. Although, the great effort of formulating overall water resource development and management strategy for the fulfillment of the objectives of the national policy, water resources of the country are not used according to its potentialities (Savenije, et.al 1998).

The overall national level objectives of Water Resource Act, 1992 focused on management and utilization of the available water resources for safe drinking water available for required quantity, increasing agricultural production and generate hydroelectricity for substituting the imports of the petroleum materials in the friendly way to environmental conservation and protection as well as to encourage consumers and private sector's participation in development, management and utilization of water resources in achieving multipurpose objectives in a complimentary way as far as possible.

The government in the ninth five-year plan (1998) emphasizes on the development of overall water resource policy and puts forth the necessity of discouraging earlier sectoral or sub-sectoral policies to move towards managing the growing inter-sectoral water using competition. Currently, efforts of formulating overall water resources development and management strategy are underway with the vision that efficient and judicious harnessing of the water resources can achieve the purpose of maximizing the sustainable benefits of water use to Nepal and thereby contribute to the significant improvement of the living conditions of Nepali people. Water resource development so far, especially in such areas as irrigation, hydropower generation, drinking water supply and sanitation, is far below its potentialities.
The Water Resource Act 2024 was the first significant action for the implications on the enactment of the Canal and Electricity. The policy on irrigation was first adopted in 2045 focusing on people's participatory management from the HMG level. In 2049, HMG came up with overall management of water resources with umbrella coverage in the form of the Water Resources Act, 2049 in more elaboration form on irrigation as well as on hydropower with Irrigation policy 2049 and Hydropower Development Policy 2049. Electricity Act 2049 and the Water Resource Regulations Acts 2050 were enacted thereafter. The Industrial enterprise Act 2049 was also amended 2049 to supplement other policy such as Hydropower Development.

In the water supply and sanitation sub sector, some policy guidelines were adopted in 2042(sixth plan) for basic needs programme. Policy relating to sanitation came out in 2050. It was only 2055 that a comprehensive policy covering both Water Supply and Sanitation, Nepal Water Supply Sector Policy, 2055 was adopted followed by Drinking Water Regulation 2055.

Irrigation Policy 2049 has clear provision of Water Users' Association to Participate in decentralized institution, capacity development, reforms for efficiency, development of technology, service fee collection for observation and management, coordination with agricultural sector, conjunctive use of water, constitute the main features of this policy. This policy also makes clear about the decentralization of authority along with the spelling out of duties and responsibilities of each institution and service provider as well as the provision of users.

Hydropower Development Policy2049, envisages on the opening up to the private sector while retaining the government's role in its development. The policy exempts licensing from small projects up to the capacity of $1000 \mathrm{Kw}$. There is reference to the cooperation 
and coordination between the private and government sectors along with the benefit sharing with the local people. Social and environmental effects have to be studied before the project implementation in order to avoid the social and environmental deterioration.

The major emphasis has been given on the maximization of using water resources, private sector involvement, expansion of rural electrification with people's participation and development of fund, priorities on domestic needs, minimization of adverse effects with project affected area and protection of environment. Beneficiaries are required to make their contribution to the development and rehabilitation of the system according to the nature of the policy.

National Water Supply Sector Policy (2055) emphasizes on the establishment of a system, which would enable the communities themselves to take up the leading role in process on the need for the need of identification, selection, formulation, implementation and management of water supply programme. It points towards the end of the HMG/N involvement in implementation of water supply and sanitation projects and strengthen institutions for decentralized service delivery. These policies also envisage on the priority to the disadvantaged people using of local resources, promotion of hygiene and sanitation and minimize environmental effects. Social, economic and technical factors are the major selection criteria for project implementation. It envisage on the hardship for fetching water, felt need of the communities and participatory level of the beneficiaries.

Most of the water supply projects shall be handed over to the users' committee, municipality, water supply related organization or community based organizations. Capital investment by the government shall not exceed 90 percent of the project cost in the case of rural water supply schemes. In the case of rural water supply projects, users committee has to deposit Rs. 1000 per tap or as decided by both the parties for Operation and Management (O\&M) fund. Government shall facilitate loan provisions from financial institutions for rehabilitation and extension of water supply projects. Industrial Policy 2049, encourages private sector industries including hydropower focusing on Industrial production to contribute more to the national economy by utilizing local resources and emphasizing in promotion of industries for employment opportunities by developing through industries.

Foreign Investment and One Window policy, 2049 focused on to build up strong economy by focusing on producing goods, generating opportunities, increasing private sector participation for productivity, mobilizing internal resources and focusing on competition of Nepalese industries in international markets.

\section{Sectoral water allocation in the Policy}

Water Resources Act of 2024 recognized the rights of individuals, group of individuals or the community to divert water from sources like streams, rivers or ground water to the extent that the extraction does not affect adversely the functioning of government irrigation schemes or hydro-power plants, in the context of using water for irrigation. Water Resources Act 2049 states that the ownership of all water sources of the kingdom will be vested in the state and people will have use-rights so that the resources is utilized for creating national assets and contribute to revenue.

There is a mechanism of sectoral prioritization of water resources in the country in order are,

i) Drinking \& domestic use, ii) Irrigation, iii) Agricultural uses (animal husbandry), iv) Hydropower, v) cottage industries, industrial enterprises mining, 6) Navigation, 7) Recreational use, and Others. 
Drinking water among the various sectors is given importance as well as active competition among the users is viable. In the river basin area, irrigation is the main sector in the water using activities. Environmental consideration is given more importance besides all these water allocations into various sectors. Policy relating to sectoral water transfer has precisely none existed with respect to inter-sectoral water transferors.

\section{People's Participation in Public/Private Sector Water Management}

Public sector participation is encouraged in water resource development by the government through water resource policy. The most visible is in the irrigation sector as evidenced by a large number of community managed irrigation systems. The role of the state provided by the policy is focused only on the technical and financial support for the improvement of the community managed irrigation system. Various projects are being implemented by the District Office of Irrigation to support their community managed irrigation systems. However, the ownership of the irrigation systems remains with the community. The Water Users Group (WUG) registered with the government agency recognized officially is not supported by the government but it is run through the participation by the community itself.

In the development of irrigation system, private sector participation is also recognizes by the government policy though Government does not provide financial and technical support. The support from other agencies such as bank, NGOs and other organizations are allowed positively. Mostly private sector participation is found in the development and operation of the shallow tube wells in the ground water sectors for the direct benefits of the people.
The recent policy of the government is to promote public/private sector participation in the development of the hydropower. The individuals or a group can obtain government license for the development of hydropower. A number of micro-hydropower projects are currently being developed privately and by groups promoted by the government in some areas where services from the grid lines are not provided. The users receive technical and financial support from the government and also mobilize their resources for development.

In the drinking water sector, the government policy is to encourage the community participation in the development, operation and maintenance of water supply systems. The government owns almost all the drinking water systems in the urban areas. However, the hand pumps in the urban areas are privately owned. License is not required for extracting ground water for any individuals and group.

Users' participation at all stages of projects implementation including decision making and cost sharing for development need infra-structures by the first irrigation policy 2049. The policy puts forward the vision of implementing joint management systems larger than 500 hac. in the hills and 2000 hac. in the plains though smaller systems than these sizes would be turned over completely to the users. The initiation through the users is given more importance for the government support by forming the Water Users Associations (WUA) from among the users. The WUA organizes and mobilizes the users and maintain linkages with the agency. The WUA is registered with the government agency in order to provide legal entity. The WUA facilitates the interaction between the users and the agency officials during the design and implementation of the project as the policy emphasizes "participatory approach". 


\section{Water User's Associations}

In Water Resources Act 2049, clearly defined about the constitution of Water Users' Association as a corporate body with the statement written in policy is "people willing to make use of water resources for collective benefits on an institutional basis may form a Water Users' Associations (WUA) as prescribed". It has to be registered as a person before the officer or authority. It becomes a corporate body having perpetual succession. It has right to acquire, enjoy, sell, dispose or arrange by any means of moveable and immovable property and it may sue or may be sued as person against it.

Those users, who wanted to utilize water from canal for irrigation is developed by His Majesty's Government, should have nine members at least including two women is allowed to form executive committee. With fixed registration fee, water users have to apply to irrigation office in the district. More than sixty-seven percent users should present to the meeting who will be automatically become general members. If the committee members do not work properly, complain from two third of the members to the related irrigation office, will dissolved through the initiation of the District Irrigation Office. For the empowerment and participation, women are involved in WUA for the equal utilization of the resources as well as their participation but it has not stated about the provision of women's participation in Drinking Water User's Association clearly.

During the field work in Thangpaldhap, Thangpalkot and Gunsa, in Indrawati River Basin area, in Sindhupalchowk district, Water User's Associations are quite active to use water resources for their benefits. Their aim is not only to use the resources but also to uplift the socio economic condition of the people with the vision to pay back their loans. Most of the water users are formed only to use the resources for getting the kulo for irrigation only.
During the implementation of the project, certain percentage of the capital costs through cash and labor contribution from the users' is required in the nominal cash contribution. Users' are allowed to implement small-scale project themselves. The users are responsible for repairing and maintaining the system by contributing the substantial level of labor. With the deviations from one systems to the other, awareness in the sense of ownership and incentives have been the prime driving forces to create institutions for resource mobilization, record keeping, sanctioning, water fee collection and account auditing for achieving distribution and production of resources in an equitable basis among users in the river basin.

The operation of the system is the sole responsibility of the users except for the government owned system. Water allocation defined the water rights of the users. Thus, the users can acquire and distribute water within users in a system. The water allocation within the system is governed by a set of rules, which is usually drawn by the users themselves. Mutual consensus on sharing water from common sources is found through user's participation in system operation among farmers and their committee members. During water deficit periods, system may share water by adopting time-based turns mostly in days and nights. In most cases, there are formal documents describing legal access to the sources. Sharing from the common intake from more than one system, the amount of water for irrigation is shared proportionately through the contribution of labor for intake maintenance.

The rules of water allocation to different places inside irrigation system is based on the time, land size, water discharge, canal net work, location and number of outlets, number of water users, type of land to be irrigate, shape of the command area, rainfall, patterns and demands of the farmers. Both formal and informal WUA are responsible to carry out operation and management related to 
acquisition, control, distribution, and using water for irrigation systematically. Resources are mobilized through fee collection and labor contribution among members.

The user's participation is limited to the development of micro hydropower only. The users have to take the full responsibility for the operation and maintenance in case of community owned microhydro after commissioning. However, they receive technical support from the government in case of major maintenance.

\section{Water Law and Legislation}

Water Law in Nepal consists of customary rights written in civil code and statutory law clearly. The customary right over water is acquired throughout year of usages as codified status in the Muluki Ain, 2020, the National code of Nepal. The right to access on drinking water and irrigation was based on prior use, i.e., first come first service basis. However, on many occasions, the users themselves have made readjustments in water use from irrigation to drinking water.

As the process of water laws, rules and regulations, Water Resource Act 2049 was the first comprehensive attempt on using water resources focusing mainly on the customary water use right recognized legally by means of the National Legal Code 2020 (1963). Public interest is given more importance than the interest of individual by HMGN and has authority to take any kind of natural resources from the country by giving compensation to the local people.

\section{Surface Water}

The legislation on water sector dates back to 2020B.S only. Water issues had seldom been a problem demanding the legal and regulatory measures in the past. Recently there has been paradigm shift in treating water as a capital commodity rather than a free commodity.

The responsibility of water management is distributed throughout different levels of administration from highly centralized level to the local bodies (to some extent). There is not any distinction on ground water and surface water in the water legislation and has not clearly written about the authority of the state over the resources of the country. State has full authority to use the water resources for the public use as well as have power to control over those people who are utilizing and mobilizing resources.

According to the Legal Code 2020(Ninth Edition), the land rehabilitation section has clearly stated "A person whoever built Kulo (small canal) has the authority to use water first. No one is allowed to restrict those people who are using it since from the beginning". Other people can use water but not from the same source. New canal can be built without hampering the situation of the previous user. The duty for the maintenance goes to users. If sharecroppers are not able to maintained, then the landlords are allowed to report to Government office if it is possible. Farmer is allowed to take water through canal to use in his land. Compensation should be given for those lands that are under the irrigation canal according to current rule.

\section{Glaciers}

Most of the river water resources are from the Glaciers though there is not any clear legal provision regarding glaciers.

\section{Ground Water}

It is important to require license for the survey and exploration and exploitation of groundwater resources in order to present interference with existing rights. It is also essential to adopt 
protective measures to prevent the depletion of aquifer but there is no regulation to take care of this aspect. The WRA 2049 defined groundwater as water resources made applicable to harvest by all users. The legislation has linked ground water directly with the surface water. The protection of drinking water sources, pollution control, ground water recharge, overdraft and water quality problems are the key issues needed to be addressed clearly in legislation. Ground water is allowed to use by the landowner who owns the land. There is no need of license to use ground water for domestic purposes in practice. Land and water rights are interrelated with each other. Right to water is related with right to land. In the case of groundwater and water in wells, rights to land and rights to water are inter-linkages directly. In the irrigation system, local people's right is attached to the rights in the command area. Rights to water are always transferred with the right to land, whether by purchase or inheritance.

State has the right over the water resources of the country in whatsoever form, even springs, wells and groundwater on private land.

The rights of individuals, or group of individuals or the community are allowed to divert water from sources like streams, rivers or groundwater to the extent that the extraction does not affect adversely to the functioning of government irrigation schemes or hydropower plants

Existing Legal Instruments for Ensuring the Accountability of Officials/Water service providers and Users

Formally there are two types of legal instruments for ensuring the accountability of water resources in the different systems.

For the irrigation development, expansion and conservation, an irrigation and river-controlled committee will be established in each district. There will be seven members in the committee. Fixed Service fee charging of three members will be there to charge fee from users after handing over the project to local user and service charge from it.

Water Resource Regulations 2049, has the provision of District water resource committee with nine members for the utilization of water resources in the District. Usually two instruments are common for the water accountability in water sectors which are, HMG Officials providing water services and Users using water resources. Officers are prescribed to provide licenses to those who apply in proper formats to utilize water resources. Contracts might be given for the utilization of water resources and fix the terms and conditions for the use of service and realize the service charge. Those who utilize the resources without any authority or misuse the services including not paying the charges properly will not allow using. The prescribed officers may cancel the license incase of contradiction to the written act as well as have authority to impose fine.

\section{Property rights}

According to the constitution of Nepal in Article 17, all citizens of Nepal have right to earn property, use it and have rights to sell and get profit from mobilizing it. For the good agricultural production, country should focus for the economic development of the people by running land reformation program to develop agriculture and to promote small industries. Women should be promoted by focusing the program of education, health and employment by making them participate to focus maximum welfare of the rural people.

The establishment of the general code of conduct while exercising the right of the public to use water to fulfill various domestic and industrial needs has recognized the customary water use right 
prioritizing for irrigation. The recent WRA 2049 regulate the exploitation and management of the nation's wealth. Permission has been allowed to utilize, conserve, manage and develop energy and to protect the environment from water pollution under the authority of the government of Nepal.

\section{Legal Provision of controlling environment and Water pollution}

Muliki Ain (tenth edition) clearly states about the prohibition of any forms of contamination to the water body limiting the access of others to use the same water as well as prohibits the discharge of water and sewage into groundwater aquifer. Irrigation Act 2049 also clearly states that no one has right to pollute water by mixing any litter, any kind of garbage, industrial development waste, and poisonous chemical waste. No one is allowed to utilize the resources hampering the environment occurring landslide, floods and erosion. The government is empowered to prescribed necessary terms and condition for carrying out such activities by any individual or organization. The government may designate environmental inspector for inspection of activities, who has causes adverse effect on the environment.

For the protection of Environment, Users are allowed to plant trees near to the canal and sub canal. The Industrial Enterprises Act, 2049 gives due consideration to environmental and pollution problem. New industries have to comply with the predetermined standards against pollution and environmental effects. The act provides some incentives for the installation of pollution control equipment. In the case of Rural Water Supply System, the intake area at the water sources is being protected through fencing against the external pollution. To extend the use of hydroelectricity for minimum utilization of fuel wood and render necessary assistance in the conservation of forest and environment, this policy has also focused on the construction and operation of hydroelectric project to have minimum adverse effect on the environment.

\section{The Existing Water Administration and its Organization functions}

For the utilization and management of country's Water Resources in a sustainable manner, various appropriate institutions are required for the development at the national, regional, district and local levels.

In spite of abundance water resources, water necessity is not fulfilled due to having imbalance between the supply and demand. Government is facing various problems on managing of water resources for the fulfillment of the necessity of water resources.

After the promulgation of the water acts and policies, most of the water resources are under the authority of government. Government's presence was the common practices in all aspects of activities in the past but People's participation is given more emphasis for the development and management of water sector in the new policies, rules and regulations.

Present organizational structure of the policy can be divided into various levels- such as coordination, implementation, operational, and regularity. According to the government's policy, the involvement of the community organizations, NGOs and the private sector to manage the water sector gradually replace government bureaucracy and its services. This results the government to move away from its involvement in resource utilization and emphasis is given for the involvement of the local community. For the appropriateness of institutional arrangements, government is supporting on the involvement of community organizations, which is declared clearly by the policy. 


\section{Inter-linkages between various organizations}

Though there are several policies, laws and legislations relating to the development and management of water resources in various sectors such as irrigation, domestic water supply and recreational work in separate department, the government institutions are not able to work alone efficiently. About the resource utilization in the river basin, all polices, rules and regulations are silent but the Ninth Five-year plan has put emphasis on the integrated development of water resources on the basis of a river basin.

Government had the whole responsibility for development and management by fulfilling the water demand of people with the help of its various numbers of departments and their supervisory ministries. Most of its new programme never included the users and it was in the unsatisfactory form. For the sustainability of using resources, new efforts were brought to encourage local people by letting them to participate in using resources as well as participate on maintenance and development of the project launched in their area.

Existing several sub-sectoral plans are lacking during co-ordination and cohesion. Sub-sectoral agencies for irrigation, domestic water supply and hydropower policies based only on their limited needs. Various conflicts over resource utilization and ecological systems might seen clearly due to the lack of coordination of various undeveloped sub sectors programme which helps to deteriorate ecological system such as lowering of groundwater level and drying up of wells in certain pocket through the destruction of the forest.

Although having various sectors and sub-sectors in various levels in different resource utilization, it is very difficult to implement the objectives through the interference of using politics by different politicians and higher-level officers. Most of the decisions are referred to a higher-level officers and it is widely practiced in most of the HMG offices.

Various main agencies are associated with the water resource association with the existing coordination level such as water resources development Council, National Planning Commission and District Water Resources Development Committees. For intersectoral water allocation, only informal arrangements are existed, such as water mills and irrigation.

There are no institutional arrangements at Indrawati river basin level to cope up with multiple use of water except WUA. With the help of some external agency, some systems are used such as minihydropower agreement with the system of Irrigation, Water Turbine and saw mill.

\section{Organizations and its Functional Management}

For the Management of Organizations, three levels of managerial functions are clearly seen. In the section of management, Policy formulation, Planning, Public participation and inter-organizational coordination, Research and Evaluation, Resource mobilization and macro-level resource allocation, Water Service Delivery Functions, Design, Construction, Operation \& Management and Monitoring and Evaluation will be conducted in the given criteria.

After the Sixth Five year plan, Government department took new programme of participating community and private sector for the sustainable development so that the burden of the government over maintenance, operations and management of any project avoid the difficulties of finding financial sources for new sectors which was under the authority of government before.

The functions of the government are carried through different layers of administrative structure with growing emphasis on community 
and private sector participation in the development and management of water sector. The organizational structure of water administration is believed to be in three levels via co-ordination level, Implementation and Operational level, and Regulatory level.

Some number of councils, commissions and line ministries are also involved at the Policy, planning and decision making level. The National planning Commission (NPC) is responsible for the national planning and coordination of all sectors. For the water sector, The Water and Energy Commission and its Secretariat (WECS) were established as a coordination and advisory body. Its ability to coordinate the numerous agencies involved in a water sector has not been found effective due to lack of explicit authority. The National Water Resources Development Council (NWRDC) has the highest authority for decision making on water related issues. Member of political party, senior government officers, and non-government officers are representing to NWRDC. The Secretariat of NWRDC is the secretariat of Water Energy Commission.

Two levels of institution on Water Resource administration and management are clearly seen such as, central level and local level. In the central level, The Ministry of Water Resources is responsible for hydropower, irrigation, disaster prevention and Ministry of Physical Planning and responsible for drinking water supply, as well as urban infrastructure, housing and roads construction. For Sub-sectoral implementation departments are placed under these two ministries including the Department of Irrigation (DOI), Department of Water Supply and Sanitation (DWSS), Department of Electricity Development (DOED), Department of Water Related Disaster Prevention and two public corporations including the National Water Supply Corporation (NWSC) and the Nepal Electricity Authority (NEA), There are also some departments related with other line ministries. The Department of Hydrology and Meteorology (DHM) has been placed under the Ministry of Science and Technology and Department of soil conservation is placed under the Ministry of Forestry \& Soil Conservation.

Under the Ministry of Water Resources, the Department of Irrigation (the DOI) is responsible for the development and management of surface and ground water. The functions of the Department are (a) planning, designing and implementation of major and minor irrigation systems and sustainable operation and management of major and minor irrigation policy. The central organizations have five divisions each headed by a Deputy Director General.

At the local level District Development Committee (DDC) is the key institution in each district for the planning and implementation of Projects. The DDC liaison with line ministry offices that located at regional and district levels, including irrigation, rural water supply, and meteorology and hydrology. For the planning and implementation of project in VDC, DDC is responsible for the coordination. Water User Association (WUA) or Water User Groups (WUG) is administered through DDCs and VDCs. Solving the dispute and licensing for water is the responsibility of District Water Resource Committee.

The Institutional mechanisms of the Water User's Association have gained popularity since from the involvement of the beneficiaries for planning, implementation, management and operation of water resource projects by following the government's strategy. The involvements of the local people in the local development program are the main efforts of the government to take over the responsibility from the government agencies for service delivery at the local level. This program might bring the ownership feeling for 
the local people as well as conservation, protection, management and utilization of the local resources.

\section{Regulatory Institutions}

According to the policy of handing over the local resources to the local people from the government side, it gives more responsibility to the government agencies to see local agency's proper work. The more the government sends the programs out to the community organizations and the private sectors, the more responsibility will be on the part of the government to see whether these functions are being carried out properly or not by the interested consumers. The purpose of regulation is to encourage or promote competition for better service and its sustainable use.

The Water Resource Act, 2049 and the related regulations provide for a set of instruments for regulation of water use. As the ownership of water resources is vested on the government, the use of water is regulated through a system of permits. A system of license has been introduced. The District Water Resources Committee in each of the seventy-five districts is empowered to grant license for their utilization. Domestic uses have been put outside the domain of licensing for practical reasons. The committee is chaired by the Chief District Officer and includes members from various district-level sectoral offices.

\section{Conflict resolution}

A Water Resource Utilization Investigation Committee at the national level has been provided with the membership of representation of the Ministry of Water Resources (MOWR) as chairman and one representative each from the concerned DDC and the regional office of the National Planning Commission Secretariat for the conflict resolution provided by the Water Act and Water
Rules and Regulations. The Water and Energy Commission will solve any kind of conflict arise to the beneficial during the utilization of water resources on large and middle project. Conflict on small and local projects is resolved by Water Resource Utilization Conflict Resolution committee where there will be four members in each district. If the conflict between two or more districts arises about utilization of water resources, the conflict will be solved by district water resource management committee focusing on water resource and energy utilization, conservation, management and development for formulating policy for advising local agencies that will have nine members.

These commission and committees will work on conflict resolution on behalf of those local individuals who are suffering from launching new projects, and trying to find out its alternative solutions focusing on total budget, total numbers of users and their problems, demands of local people, and the effects to village and environment.

If the dispute is related with two or more districts, one representative from each of the concerned DDCs will be the member of the Committee. The Regulations provided for the guidance of the committee, detailed factors to be considered while deciding on the dispute. User Group Association is also a good dispute resolution institution in the local level.

Inter-system conflicts are mainly attributed to the use of common sources, whereas intra-system conflicts mainly arise from method of water distribution often occurred during dry season or low water flow periods.

In Sindhupalchowk district, there are several cases about filing report on selling of the license of resources utilization in the district. District Development Committees have filed cases in district against District Water Resource committee that no one has 
right to sell the license of using resources of the district to any person, where all the resources of the country is vested to His Majesty's Government.

In community level small disputes are solved among the user in the village in front of VDC members. Before coming to the VDC, conflict is solved among the wards members. If it is difficult to solve in the wards, then it will go to VDC and if it is not possible to solve in the VDC level then it goes to the District level.

Inter- system, conflict has been mainly for agricultural use for irrigation, water turbine and water mills (Ghatta) in Indrawati river basin. Constructing new Kulo from the same source by the user of same ward or some times by other VDCs arises due to the lack of water resources. Sometimes, people who have not participated during the labor work, paid cash for the necessary fees and repairworks. More conflicts occurred due to water scarcity among users which have been solved through users themselves. For minimizing the conflict within the system, different water rotation schedules have been found in practiced helps to reduce conflict in the river basin area. Institutional Arrangements for Managing Water

Water User's Association is given preference during handing over of any kind of projects related with using water resources from government to local users. In Indrawati River basin area, various WUA related with Irrigation and drinking water systems were formed during launching the program in the VDCs level. Now most of the WUAs are defunct and have never changed their committee member, which is supposed to be changed according to their operational plan.

Politics plays important role on using resources. Only very few people especially elites are active on launching program in their areas and got benefited to use the resources who have large amount of land and wanted to have irrigation project in their field.
Policy are lacking in inter sectoral water transfer system and inter water basin system to use local water resources. For inter sectoral water allocations, only informal arrangements existed as a forms of water mills and irrigation. ]

\section{Resource Mobilization}

For the social and economic upliftment of the society, utilization, management and protection of water resources without hampering its condition should be given importance for the successful livelihood, through encouraging local people during using local resources by themselves in the guidance of government. To use and mobilize water resources in maximum level, government has made several rules and regulations related with different resources in different Acts. Different provisions such as water pricing, cost recovery and revenue collections are clearly written in these Acts also.

At present, in medium and large surface irrigation projects, government constructs the major infrastructure, while the users associations are supposed to construct their minor cannels. In small Agency Managed Irrigation System (AMIS), deep tube well system and rehabilitation of Farmers Manage Irrigation System Users Association (FMISUA) have to share from 5 to $15 \%$ of the construction cost during management.

The Department of Irrigation (DOI) until the Sixth Plan Period had focused all the attention in the development of infrastructures of irrigation schemes. After completion of the projects, the operation and maintenance of AMIS remained full responsibility of DOI, whereas the users were expected to pay service fee to meet the operation and management cost.

Stakeholders are the one who initiate to bring new projects in their place so some time farmers are found to attempt or exert their social 
and political power to use more water and convert their dry land into paddy field for cultivating rice. Generally they are found to be reluctant and in most case opposed sharing of water with the new users in the lowest rates. The state intervention and expansion of the command area with financial support from the government, farmers in the upper canal have been found to be ready in adjusting their water rights by sharing with other people from the tail end of the canal. As an example, In Indrawati river basin area, new kulo was built from the government support though the new kulo system might not help to include all users due to the geographical condition of the settlement People suspected that New Kulo might be failed to run water for irrigation after using lot of money from the government and labor contribution from the farmers. Before launching the project to the area, feasibility survey about the water sources for sufficiency for the future, household survey, attitude of the local people about their belief, and tradition, should be studied to prevent from over cost and long lasting utilization.

\section{Water Pricing}

In Water pricing systems of Nepal, the traditional cost accounting approach and pricing is usually linked to the cost recovery of Operation \& Management (O\&M), required to produce services. Basically water pricing was based on the demand-based management, goals for the generation of revenue for operation and maintenance and extension of the system. Irrigation projects are viewed as instruments of development especially for augmenting income (poverty alleviation also), generating employment and food production. The pricing based on the traditional cost accounting approach has also not been done effectively due to the political pressure on fixation of tariffs.

In Nepal, for rural water supply and irrigation sub-sectors, O\&M cost recovery-pricing approach is used. While pricing for urban water supply and electricity, traditional accounting approach of costing is practised. The most recent electricity tariff fixation is, however, a departure from the traditional accounting approach to cover capital cost and depreciation. Electricity prices are fixed also to cover the investment needs for future expansion of electricity services.

One of the strategies for effective water demand management is to establish and implement appropriate water pricing policies that encourage efficient use of water and discourage waste. Water pricing policies is instrumental in achieving important goals as revenue generation for capital recovery, operation and maintenance and extension of the system, promotion for the efficiency in the protection of quality of water resources by reducing the waste discharge.

According to the user pay principle, water users' should pay full cost of resource utilization including operation, maintenance, and cost of the resource development. In the process of setting water tariff, equality and equity is given preferences while using water resources equally. In irrigation, WUAs has full authority and responsibility after the implication of these systems. O\&M responsibility goes to the WUAs in small and medium systems after transfer. Charges are collected by WUAs. In large project DOI is responsible for other parts of the project besides WUAs responsibility. On the other hand, it also reflects the strengthening of institutional capacity for sound operation of the whole system.

With the initiation of government agencies, and with the help of external intervention, local people formed Water User Association or Organization to fulfill the need of irrigation scarcity by making water canals for irrigation as well as for micro hydro power in Thangpaldhap, Sindhupalchowk. Phalame Sanghu irrigation projects, Chureta irrigation projects, Kalidaha beltar Irrigation 
projects, Taruni besi Irrigation projects, Besi ko kulo, Chimti irrigation project are the main irrigation projects to irrigate the land which help people to convert their unirrigated land. Due to availability of water, the process of converting cropping pattern from two cropping system to three cropping system is common in Thangpaldhap VDC. Three types of crops are produce within one year. Paddy, Chaite Paddy, and Wheat. For Wheat and Chhaite paddy, irrigation is needed. For the good production of Chhaite paddy, Wheat and Kitchen vegetable garden, irrigation is important. Farmers do not have to pay regularly to the government but during building canal farmers have contributed their labor. People paid for the Ghatta owner for grinding flour but not any kind of fee paying system within Users.

The sources of the water in most rural areas are far away from the settlement. Some time sources might not be sufficient for the total village settlement. Rural people still feel that water is a free commodity so hesitation for using for paying water charges is common. Adequate revenue by collecting water charges from the consumers is expected to pay village maintenance workers and caretakers, to meet the expenses for the purchase of required spare parts and other inputs in order to maintain the sustainability of the water supply. For rural water supply, the cost of administration is not so significant. But there are no proper water tariff structures or effective arrangements are existed.

Ehchowk drinking water project was established on 2046. Five thousand households were benefited from 340 drinking water taps but only very few taps are on used. The project was covered to one to five wards in Kiul VDC. Twenty rupees from each household were collected for the drinking water projects besides all the support from the government side. Nangi Danda drinking water projects was established by depositing some amount of money in district drinking water office.

\section{Water pricing for urban water supply}

A structured water tariff has been designed by Nepal Water Supply and Corporation which covers the cost involved in operating, repairing and maintenance, depreciation or debt service, which is higher than working capital requirement. The water tariff has been fixed under the following principles and criteria on their consumption basis are the minimization of wastage of water through meter connection and the size of the connection, affordability, tariffs based on the cost of production and encouraged public to connect sewerage in order to promote public health and sanitation.

Mobilization of natural resources in maximum level costs millions of rupees so after mobilizing it; the cost benefit must be recovered by selling it to the user. Electricity pricing has been determined mainly on the basis of financial or accounting criteria, e.g. raising sufficient sales revenue to meet operating expenses and debt service requirements while providing a reasonable contribution towards the capital required for future power system expansion.

Three different grounds of electricity pricing are practiced such as Electricity distributed through the national grid, the electricity tariff and other charges on the basis of rate of depreciation, reasonable profit, mode of operation of the plant, change in consumer's price index, royalty as mentioned in the Electricity Act 2049.

\section{Cost Recovery System}

As the primary organization, department of irrigation is responsible for planning, development and management of irrigation systems in the country. In terms of ownership, irrigation system is classified into two groups such as agency managed and farmers managed 
systems. The agency-managed systems are designed, constructed and managed by the government and farmer managed systems, are constructed and managed by the farmers themselves.

It is important to achieve the collected irrigation service fees (ISF) for the O\&M cost recovery of the irrigation system. In most of the irrigation projects mostly money has been vested for the benefit of the local people by involving them to work in their local irrigation projects for their uplift of their livelihood. Only their labor contribution is asked to make them feel that the project belong to them. The collections of recovery cost are all needed for their future O\&M. In Drinking water supply and sanitation in rural areas, O\&M cost recovery is actively collected in those areas where there is the intervention of external agencies such as in ADB supported areas. In this areas water user' group committees are actively functioning, village maintenance woks are carrying out routinely on O\&M and users are paying for service, where water user committees are not active and are almost on defunct form. Nepal Water Supply Corporations (NWSC) is responsible for planning, implementation, operation and management of urban water supply in the country. It is authorized to fix the water charges on the basis of cost plus recovery approach but full (replacement) cost recovery is tried to be analyzed because the targeted return on investment is the policy variable that may vary in different situation.

Nepal Electricity Authority (NEA) is responsible for planning, designing, constructing operating and maintaining of generation, transmission and distribution of electricity in the country. The NEA is producing electricity from both hydro and diesel projects. Electricity is also produced by the private sector. NEA purchases most of the electricity produced by the private sector in Nepal.

\section{Conclusions}

Water resources are wealth of nation. Nepal's unused water wealth is flowing away in absence of good programming and financial constrain. Every society has their own local rules and regulations to mobilize resources for their benefit. The external intervention from the government agencies and other foreign intervention bring support as well as confusion among the user which has been seen from the case studies of some of the farmer managed irrigation systems in Sindhupalhowk district.

Most of the Water user groups are defunct. Water User Association was formed during making kulo, irrigation canal or micro hydropower but committee meeting was never held except in some WUA. Lack of awareness on using resources as well as feelings of ownership over the project is clearly seen. People's participation is not sufficient for the sustainable rural livelihood, people's awareness is also important for making people participation for the development. Rules and regulations must be clear and understandable which could not contradict with each other during implementation. The policy of water pricing and cost recovery must have clear provision about the state's role and user's role. Water resources in Nepal should be mobilized in its full potentialities through the proper institutional arrangement and management. The policies, rules and regulations of using country's water resources should be analyzed and try to fill the gap between water related institutions.

\section{Reference Cited}

Bandaragoda, D.J. 2000 A Framework For Institutional Analysis For Water Resources Management In A River Basin Context. International Water Management Institute. Colombo, Sri Lanka.

Bhattachan, K.B 1997 People/Community-Based Development Strategy in Nepal. A paper presented in a seminar on Development Practices in Nepal. Organized by the Central Department of Sociology and 
Anthropology with support of the Friedrich Ebert Stifung (FES), Kathmandu on March 10-11, Nepal.

Dhakal, Suresh 1996 Bheja As A Strategic Cultural Convention: Community Resource Management in the Barha Magarat. Emerging Ethnicity and Aspects of Community Adaptation. Occasional Papers in Sociology\& Anthropology, Central Department of Sociology \& Anthropology Tribhuvan University.

Electricity Development Center 1996 Nepalese Legal Provisions on Hydro-Power Development. Exhibition Road, Kathmandu.

HMG/N 1992 Hydro power Development Policy 2049, Ministry of Water Resources, Singh Darbur, Kathmandu.

HMG/N 1992 Nepal Electricity Act 2049, Ministry of Water Resources, Singh Darbur, Kathmandu.

HMG/N 1993 Water Resources Regulations 2049, Ministry of Water Resources, Singh Darbar, Kathmandu.

HMG/N 1996 Water Resources Act 2049 Ministry of Water Resources, Singh Darbar, Kathmandu.

HMG/N 2047 (B.S.) Constitution of Nepal. Law Justice and Parliamentary Ministry. Kanoon Kitab Babastapan Committee.

HMG/N 2056(B.S.) Local Governance Act 2055. Kanoon Kitab Babastapan Samitti, Ministry of Law and Justice.

HMG/N 2056(B.S.) Local Governance Regulations 2056 and Local governance rules 2056. Kanoon Kitab Babastpan Samiti, Ministry of Law and Justice.

HMG/NPC 1998 The Ninth Plan(1997-2002).

Jepperson, Ronald L. 1991 Institutions, Institutional effects, and Institutionalism. In Powell, Walter W.; and DiMaggio, Paul J. (eds). Institutionalism in Organizational Analysis. Chicago: University of Chicago Press.

Merg, Juerg et.al (ed.) 2003 Water and Rural Watershed: Middle Mountains of Nepal. Translating Development: The case of Nepal. Edited by Manfred Domroes
Merrey, Douglas, J. (ed) 1993 Institutional contexts for managing irrigated agriculture. The Institutional Framework for Irrigation, Proceedings of a workshop held in Chiang Mai, Thailand, 1-5 November1993. Colombo, Sri Lanka: Irrigation management Institute. pp.7-22

Muluki Ain. 2051(B.S.). Law Justice and Parliamentary Ministry. Kanoon Kitab Management Committee. Tenth edition.

Savenije, Herbert H.G et al. 1998 Management of Shared River Basins: Focus On Development of Effective Water Management Institutions. Colombo, Sri Lanka: International Water Management Institute.

Soussan, John (ed.) 1998 Water/Irrigation and Sustainable Rural Livelihoods. Sustainable Rural Livelihoods. What contribution can we make? Papers presented at the Department for International Development's Natural Resources Adviser' Conference.

Taylor, E.B 1991 Dictionary of Anthropology. GOYL SaaB. Delhi 